\title{
Australia's coastal fisheries and farmed seafood: an ecological basis for determining sustainability
}

\author{
Trevor J. Ward ${ }^{a}$, David J. Booth ${ }^{a}$, Peter G. Fairweatherb, John R. \\ Fordc, Gregory I. Jenkins ${ }^{d}$, Michael J. Keoughc, Jeremy D. Prince ${ }^{e}$, \\ Christopher Smyth
}

aSchool of Life Sciences, University of Technology Sydney, PO Box 123 Broadway 2007, NSW, Australia; (after first author, all authors are listed alphabetically)

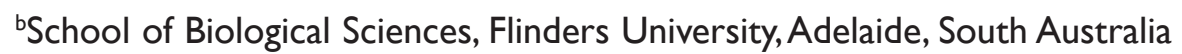

'School of BioSciences, University of Melbourne, Melbourne, Victoria

${ }^{\mathrm{d}}$ Australian Centre for Applied Aquaculture Research, South Metropolitan TAFE, Fremantle, Western Australia

${ }^{e}$ Centre for Fish and Fisheries Research, Murdoch University, Perth, Western Australia

fVictorian National Parks Association, Melbourne, Victoria

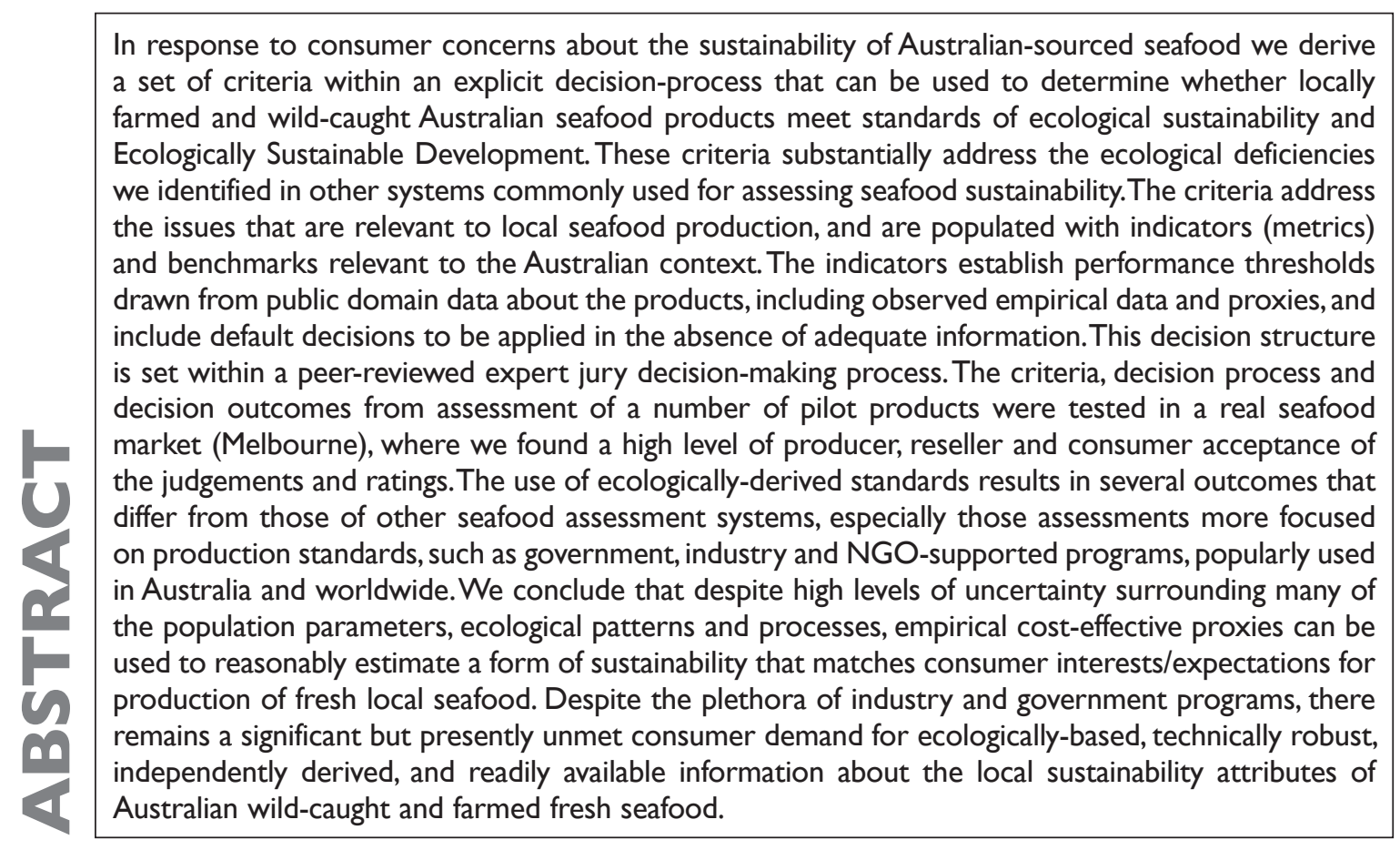

Key words: aquaculture, ecological integrity, ESD, expert panel, seafood rating system, small-scale fisheries

DOI: http://dx.doi.org//0.7882/AZ.2016.016

\section{Introduction}

The ecosystems and habitats of the world's coastal oceans are under many pressures (MEA 2005), and in Australia as elsewhere this includes the pressures imposed by wildcatch fishing and aquaculture systems (SEC 2011; Gascuel et al. 2016). The production from Australia's fisheries is in persistent decline, and may be related to decline in environment quality and increased fishing pressures in some places (Ward 2014). In wild-catch fisheries, the decline in production is a trend that has persisted across many of the fished species in recent decades-Australia's total wild catch production was 223,000 $\mathrm{t}$ in 1997-98 (Caton and McLoughlin 2000), but declined to $157,000 \mathrm{t}$ in 2012-13 (Stephan and Hobsbawn 2014). Currently, the largest wild-catch fishery is the Australian sardine fishery, in southern waters adjacent mainly to NSW, Victoria, South Australia and Western Australia, with a 2012-13 catch of 38,000 t, declining from the peak catch of 47,000 $t$ in 2004-05 (Flood et al. 2014), mainly fished for aquaculture feed and pet food. In contrast, there has been a substantial increase in farmed Australian seafood over the last 10 years, principally farmed Atlantic Salmon from Tasmania and Southern Bluefin Tuna from South Australia, although other farmed products have been either steady or in decline (Stephan and Hobsbawn 2014). 
The impacts of wild fishing and farming native marine species are complex and highly uncertain, and although Australia's fishery and aquaculture management practices strive to be highly precautionary, there remain many issues that are yet to be resolved. Central uncertainties include the widespread use of production objectives to set approved levels of catch from wild fisheries, and whether these are protective of the natural populations of fish and retain their normal levels of ecological function. In aquaculture, a key problem is the management of sea cages to avoid diseases and environment impacts on the seabed and surrounding habitats. While such issues are also worldwide problems, they are more complex in Australia's ecosystems because of the high levels of diversity and endemism in the marine flora and fauna, which imply a higher level of vulnerability to such uncertainties. For example, of the 3855 species of fish recorded from Australia's continental shelf waters $(0$ to $200 \mathrm{~m}$ depth), 945 species (25\%) are considered to be range-restricted Australian endemics (Atlas of Living Australia 2015). Since marine ecosystem quality and function is closely linked to diversity (Palumbi et al. 2009), where diversity is high, even local impacts from fishing or aquaculture operations are potentially of high significance in terms of indirect effects on both the target and nontarget populations and ecosystems.

The direct and indirect ecological effects of fishing the target species are poorly understood, and this includes the direct impact of reducing the population size of the target species, typically to levels of total biomass between 20 and $40 \%$ of that which would have existed in the absence of fishing. Even where there has been an intensive base of scientific knowledge and fishery management, fishery crashes still regularly occur, resulting in the closure of fishing grounds, sometimes for decades. Australia's school shark fishery, for example, was overfished for many years and the population remains depleted. Nonetheless $210 \mathrm{t}$ was caught in 2013 as bycatch to other fisheries, reducing the rate at which the school shark population might be able to recover from very low levels of abundance (Caton and McLoughlin 2000; Flood et al. 2014). In aquaculture, there are persistent concerns about the impacts on local environments in many locations, including wastes discharge, high densities of cages/ponds, escapes, spread of diseases, attraction of predators, and provision of energy subsidy to native (and sometimes introduced) species that congregate around facilities, such as sharks, seabirds and starfish.

Other fishing/seafood issues that also directly attract consumer attention include the closing of inshore fisheries in peri-urban areas (such as in Port Phillip Bay and Westernport, Vic; Cockburn Sound, WA), bycatch of endangered species, and the pervasive decline in commercial fish catch in most jurisdictions (e.g. in Western Australia; Figure 1). These uncertainties, together with the complexity of the governance structures (national, state, local, industry) and the dominance of commercial interests in management decision-making have created a consumer demand for independent information about the seafood sustainability attributes, and this has become an important part of purchasing decisions in Australia.
In 2007, the Australian Conservation Foundation (ACF) approached us to develop a seafood ratings program that would identify fresh seafood products that could be supported by ACF in the marketplace (mainly in Melbourne) as being produced in an environmentally responsible and sustainable manner. The ACF objective was to be able to provide both independent and technically robust information to seafood consumers, so their choices could be informed with reliable and unbiased information about the ecological impacts of the available locally sourced products. We subsequently developed a set of criteria, and a decision-making process to identify and rate products that conform to the criteria. The ratings program, known as the Sustainable Australian Seafood Assessment Program (SASAP), was designed to focus on commonly available fresh seafood products, both wildcatch and farmed, sourced from the continental shelf, inshore marine ecosystems, bays, estuaries, and coastal rivers. Products from these coastal areas around Australia form a large segment of the 'local seafood economy', and are an important resource for employment and small-scale local business enterprises in many, if not most, coastal Australian towns and shore-line settlements.

The concept of sustainability has many dimensions, but in the Australian context it has been interpreted and restated by governments within the construct of Ecologically Sustainable Development (ESD) as '... governments agreed that society could have both growth and environment protection provided decisions were guided by principles designed to maintain ecological integrity for future generations.'(emphasis added) (Burnett 2015). However, it appears that this key outcome objective has been actively and effectively avoided in a number of sectors, evidenced in key indicators that are persistently in decline: '...the efforts of governments, not only to interpret ESD but also to avoid it, by adopting a number of "pseudo-sustainability formulations". This was to avoid the difficult trade-offs arising from the ecological constraints inherent in applying ESD' (Burnett 2015).

In the context of Australian seafood production and the SASAP, maintaining ecological integrity is a central attribute of sustainability and ESD, and should thus be a primary outcome targeted by activities in Australia's fishing and aquaculture sector. While ESD also embodies interactions within the social, cultural, recreational and business aspects of sustainability, achieving positive outcomes in these alone in the seafood sector will not achieve the ecological integrity objective that is fundamental to ESD. The evidence of persistently declining catch, the ongoing range of related environmental issues, and widespread evidence of declining indicators (Ward 2014), suggest that many policies and practices in the seafood sector may be inappropriately focused and only weakly apply precaution, and therefore be best classified as 'pseudo-sustainability' (sensu Burnett 2015). Such potential failure to correctly address the ecological integrity aspects of ESD for seafood is therefore a key factor in consumer interest in better, independent and authoritative information about seafood. 


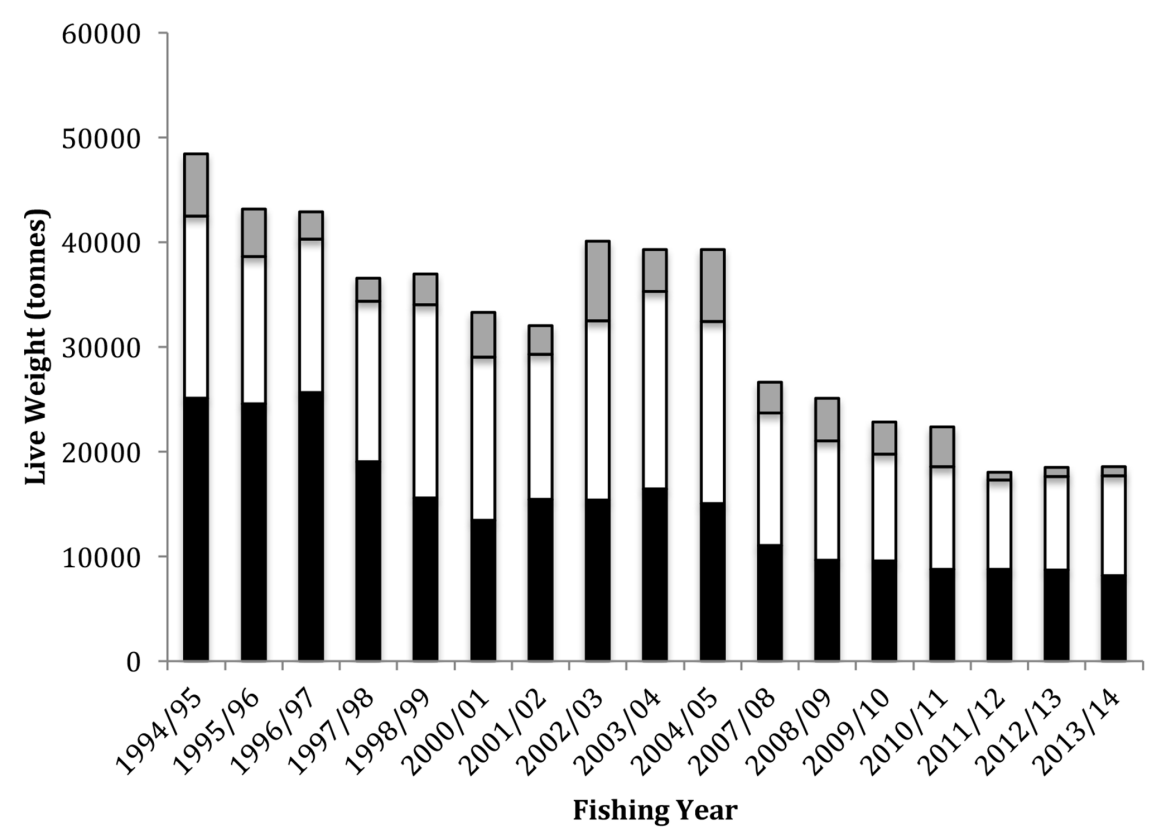

Figure I. Last two decades of commercial catch of seafood (fish $\square$ I 63 taxa, crustaceans $\square$ I 5 taxa, molluscs $\square$ I0 taxa) from Western Australia inshore and continental shelf waters (source: commercial fishers mandatory monthly reports, Annual State of the Fisheries Reports, WA Department of Fisheries; compiled annual data for the years 1999/00, 2005/06, 2006/07 are not available in public domain).

In the environmental and ecological dimension of the seafood sector, we considered that the effects of the seafood capture/production process on the structure and function of target and non-target species, habitats and ecosystems can be applied as proxies for ecosystem integrity. To achieve sustainability and ESD, impacts on ecological integrity need to be minor and capable of being demonstrated to be constrained to a level considered by consumers to be acceptable as the environmental 'cost' of the production of seafood.

Our objective in developing the SASAP is to produce a ratings system for seafood that is accessible to smallscale fishing and farming systems, is technically robust to provide consumers, chefs and restaurateurs with reliable and independent sources of ecologically relevant information, and would enable producers to access high quality technical advice if specific areas of poor performance are identified through the SASAP process. These principles guided all aspects of the SASAP criteria development and implementation towards an assessment of the extent to which a specific seafood product could be considered to be produced in a way that minimally impacted any aspect of ecological integrity.

Here we report the results of a review and criterion development process focused on ecological integrity for ESD (sensu Burnett 2015), and provide some selected examples of the seafood product assessments used to pilot and refine the SASAP program. To guide the development of a set of issues to be considered, we reviewed the criterion structure of ten other seafood assessment programs, and the processes they used to make decisions and formulate evaluations/recommendations. From this broad review of existing global practice, we derived the underpinning ecological issues and a process of decision-making suited to the type of issues and extent of data/information available for Australia's coastal seafood products. While we found many assessment system objectives were framed in ecological terms, many were assessed using performance benchmarks derived to satisfy production objectives rather than ecological objectives and standards. Therefore, here we present an interpretation of the relevant issues in an overtly ecological context, and resolve those into indicators/ standards with benchmarks that are appropriately framed to match available data/information streams, assess the ecological issues, and provide ratings suitable for communication to interested consumers.

We also reviewed the structural approach for decisionmaking in several of the systems, to inform development of a decision-making process for the SASAP that is costeffective for local-scale producers, and achievable in the context of typically available information/data about the local species and the ecosystems. The SASAP system was then taken to pilot implementation, including assessment of a range of farmed and wild-catch species, presentation of our findings in the public domain, and engagement with a number of promotional events involving various seafood resellers and consumer interfaces to gauge the level of producer, reseller and consumer acceptance and effectiveness of the SASAP.

\section{Criteria Development}

To establish an initial set of issues to be considered for SASAP criteria, and to assist with framing the levels that should be encoded into the performance gradient for each indicator, we reviewed the details of ten major seafood sustainability initiatives from government, industry or NGOs with details available in the public domain (Table 1). The criteria and indicators of each sustainability program were considered for application 
Table I. Seafood assessment systems reviewed to identify consumer issues in relation to Australian issues

\begin{tabular}{|c|c|}
\hline Program & Product, region focus, sector \\
\hline $\begin{array}{l}\text { Aquaculture Stewardship Council (ASC) } \\
\text { (www.asc-aqua.org) }\end{array}$ & Farmed products, global, NGO \\
\hline $\begin{array}{l}\text { Australian Bureau of Agricultural and Resource Economics and } \\
\text { Sciences (ABARES) \& Fisheries Research and Development } \\
\text { Corporation (FRDC) (www.fish.gov.au) }\end{array}$ & $\begin{array}{l}\text { Wild-catch and farmed species, Australia, } \\
\text { government }+ \text { industry }\end{array}$ \\
\hline $\begin{array}{l}\text { Australian Government Department of the Environment, Environment } \\
\text { Protection and Biodiversity Conservation Act } 1999 \text { Guidelines for the } \\
\text { ecologically sustainable management of fisheries (EPBC) ( } w w w . \\
\text { environment.gov.au/marine/fisheries) }\end{array}$ & $\begin{array}{l}\text { Wild-catch and farmed species, Australia, } \\
\text { government, environment protection }\end{array}$ \\
\hline $\begin{array}{l}\text { Australian Marine Conservation Society (AMCS) (www. } \\
\text { marineconservation.org.au) }\end{array}$ & Wild-catch and farmed species, Australia, NGO \\
\hline Friend of the Sea (FOS) (www.friendofthesea.org) & Wild-catch and farmed species, global, NGO \\
\hline Marine Conservation Society, UK (MCS-UK) (www.fishonline.org) & Wild-catch and farmed species, UK, NGO \\
\hline Marine Stewardship Council (MSC) (www.msc.org) & Wild-catch fisheries, global, NGO \\
\hline $\begin{array}{l}\text { New England Aquarium, Boston, USA (NEAQ) } \\
\text { (www.neaq.org/conservation_and_research) }\end{array}$ & Wild-catch and farmed species, USA, NGO \\
\hline Ocean Wise, Vancouver Aquarium, Canada (www.oceanwise.ca) & Wild-catch and farmed species, Canada, NGO \\
\hline $\begin{array}{l}\text { Seafood Watch, Monterey Bay Aquarium, USA (SW) (mww.seafoodwatch. } \\
\text { org) }\end{array}$ & Wild-catch and farmed species, USA, NGO \\
\hline
\end{tabular}

in the context of the Australian environment and jurisdictions, based on the published procedures for evaluating the performance of the different forms of seafood sustainability and certification/rating systems (Leadbitter and Ward 2007; Ward 2008a,b; Phillips and Ward 2009; Ward et al. 2011; Pitcher et al. 2013).

After evaluation of each of the programs for direct applicability in the Australian context (Table 2), we adopted the broad approach and rating system of the Seafood Watch (SW) program, and selected a number of SW criteria as the initial basis for the SASAP. Specific details of the criteria, and the performance grading encoded into the SW system, were modified to recognise the different circumstances that prevail in Australia compared to the USA, where most of the products assessed by SW at that time were produced or marketed. As a result, for the SASAP, for example we amended the SW formulations of both criteria and performance gradings in assessing the availability and use of scientific advice within the fishery management system. Other SW criteria and performance gradients were adapted to better suit the highly data-limited situation of most Australian coastal fisheries by using simpler empirical and precautionary 'rule of thumb' indicators where resolution was considered to be appropriate.

After the initial draft, SASAP criteria/indicators were internally tested using a series of workshops to reach consensus with $\mathrm{NGOs}$ and industry representatives about both the form of the criteria to be used and the performance levels to be encoded into the assessment system. This included further refinement of the application of precaution, the proxies and surrogates that may be derived from empirical data used to estimate performance in key areas, and the grading scales we expected to apply in assessing a seafood product.

\section{Results}

The key ecological issues identified in the reviewed programs (Table 2) as of concern to Australian seafood consumers were:

- Wild-catch Products: the impact of fishing on target and bycatch species, on ecologically-dependent species, and on associated ecosystems and habitats

- Farmed Products: the location/site impacts of aquaculture, genetic impacts of escapes and local trophic subsidies, diseases, chemical contamination, and the sustainability of feedstock, including the secondary impacts on baitfish populations such as use of 'trash' fish.

In wild-catch fisheries worldwide, there is widespread use of complex population-based models, typically using production objectives and standards for surplus yield and self-sustaining populations as the basis to determine an appropriate level of fishing effort and consequent catch of target species. In Australia, the increasing use of highly complex stock assessment models based on limited empirical data has had several potentially undesirable ecological consequences for the populations of species being fished. These issues include the lack of adequate precaution in setting of acceptable levels of effort/catch, permitting population levels to be routinely reduced to levels that are likely to have widespread ecological impact on structure and function of coastal ecosystems, as well as a high risk of failure to adequately maintain acceptable levels of spawning biomass for production purposes (even though production may be optimised in the short term).

Typical potential consequences of managing fish populations for production purposes rather than for their role in maintaining the integrity of ecological systems include:

- reduction of the population biomass of fished species 
Table 2. A summary of the attributes of selected sustainability assessment programs (from Table I) relative to the requirements for a robust and effective ecological sustainability assessment program for Australia's coastal and small-scale seafood products. (Note that this is a summary of the attributes of the systems as they existed in 2007-08, and they may have changed since that time, including resolution of the deficiencies outlined here.)

\begin{tabular}{|c|c|c|c|c|c|c|}
\hline \multirow[t]{2}{*}{ Programs assessed } & \multicolumn{6}{|c|}{ Criteria used for assessment } \\
\hline & $\begin{array}{l}\text { I. Publicly } \\
\text { available } \\
\text { decision } \\
\text { system and } \\
\text { criteria }\end{array}$ & $\begin{array}{l}\text { 2. Consistently } \\
\text { applied high } \\
\text { standard for } \\
\text { species in } \\
\text { ecosystems }\end{array}$ & $\begin{array}{l}\text { 3. Compatible } \\
\text { with small-scale } \\
\text { producers }\end{array}$ & $\begin{array}{l}\text { 4. Independent } \\
\text { evidence- } \\
\text { based and } \\
\text { peer-reviewed } \\
\text { assessments }\end{array}$ & $\begin{array}{l}\text { 5. Assessment } \\
\text { interaction } \\
\text { with producers }\end{array}$ & $\begin{array}{l}\text { 6. Data, } \\
\text { information } \\
\text { requirements } \\
\text { match those } \\
\text { available in } \\
\text { Australia }\end{array}$ \\
\hline ASC & yy & y & $\mathrm{n}$ & yy & yy & $n$ \\
\hline ABARES/ FRDC & y & $n$ & $\mathrm{n}$ & y & y & yy \\
\hline EPBC & y & $y$ & $\mathrm{n}$ & $y$ & $y$ & yy \\
\hline AMCS & $n$ & $?$ & $?$ & y & $\mathrm{n}$ & $?$ \\
\hline FOS & $n$ & $?$ & y & $?$ & yy & $?$ \\
\hline MCS-UK & $n$ & $?$ & $?$ & y & yy & $?$ \\
\hline MSC & yy & $y$ & $n$ & yy & yy & y \\
\hline NEAQ & y & $y$ & $?$ & y & yy & $?$ \\
\hline OceanWise & $\mathrm{n}$ & $?$ & $?$ & $?$ & $?$ & $?$ \\
\hline SW & y & y & y & yy & y & $?$ \\
\hline SASAP (this system) & $y$ & yy & yy & yy & yy & yy \\
\hline
\end{tabular}

Key: $y y=$ highly suitable; $y=$ suitable to some extent; $n=$ suitability too limited or too difficult to apply; ? = suitability unable to be determined because of lack of adequate publicly available information.

to around $30 \%$ of the expected unfished biomass (commonly held lower for many species, higher for a few - Flood et al. 2014);

- truncating the structure of fished populations to comprise mainly the juvenile and just-mature individuals_e.g. in the coastal waters of NSW, Mulloway (Argyrosomus japonicus) lives to at least $24 \mathrm{y}$, and possibly up to $45 \mathrm{y}$, yet the catch is persistently dominated by small and immature fish $(98 \%$ of the commercial catch is $<5 y$ old fish), indicating an overfished population. Until recently, in this fishery the minimum legal length was 45 $\mathrm{cm}$, much smaller than the size at sexual maturity $(\sim 70$ $\mathrm{cm}$ ) for females (Industry and Investment NSW 2010)

- likely resulting in structural and functional population level impacts on species ecologically connected to the target species (as considered to occur elsewhere for fished species and ecologically dependent species Smith et al. 2011; Froese et al. 2016)

- contributing to genetic changes resulting in loss of population resilience, earlier maturation of individuals and hence progressive reduction in the dominant size/ age class in the population (Melville-Smith 2011).

As a result of such issues, and because many of the fisheries addressed by the SASAP are small (in terms of catch) and consequently have a limited base of knowledge and capacity for research, the SASAP criteria and indicators make extensive use of proxies and surrogates. The SASAP also sets conservative precautionary benchmarks for indicators and default grades where the knowledge base is too weak to assign defendable evidence-based grades. These inform the decision-process with a pragmatic set of indicators and benchmarks designed to provide a rapid and ecologically sensitive estimate of the impacts in the issues we considered to be associated with the coastal fisheries and aquaculture systems. For example, in assessing the impacts of targeted fishing for black bream (Acanthopagrus butcheri) in Gippsland Lakes, SASAP decisions about the magnitude of population impacts were informed by research data that identified recruitment events propagating through the time-series of population structure, as reflected in the age/ size structure of fish in the fishery catches. While there were concerns about the short-term trend for reductions of older fish in the catch, this was considered to be within historic patterns (and potentially related to the dynamics of river inputs to the lakes system) (Kemp et al. 2013).

The SASAP decision system for assessing the seafood products comprises a set of criteria, sub-criteria, indicators and performance benchmarks framed at the population and ecosystem level. For wild-caught products, the criteria cover the three central elements of the sustainability decision problem (Figure 2): status of wild stocks (target and byproduct ${ }^{1}$ species); bycatch; and impacts of fishing on habitats and ecosystems ${ }^{2}$. For farmed products, the

\footnotetext{
Bycatch is any plant or animal other than the target species that is taken by fishing gear or damaged during fishing operations. Byproduct is marketable species that are taken incidentally by the fishing gear and retained for sale. While some forms of bycatch can be returned alive to the ocean if they are handled carefully, delayed discard/ release mortality is high for many species, and predators are often entrained on fishing vessels to feed on discards, resulting in high levels of unintended discard mortality for some forms of bycatch. Catch and release is therefore not necessarily a practice with insignificant mortality on target or bycatch species.

2 Gear types that make contact with the seabed may have direct physical impacts on sedentary assemblages of plants and animals. Ecosystem impacts may occur when large proportions of a local population are
} 


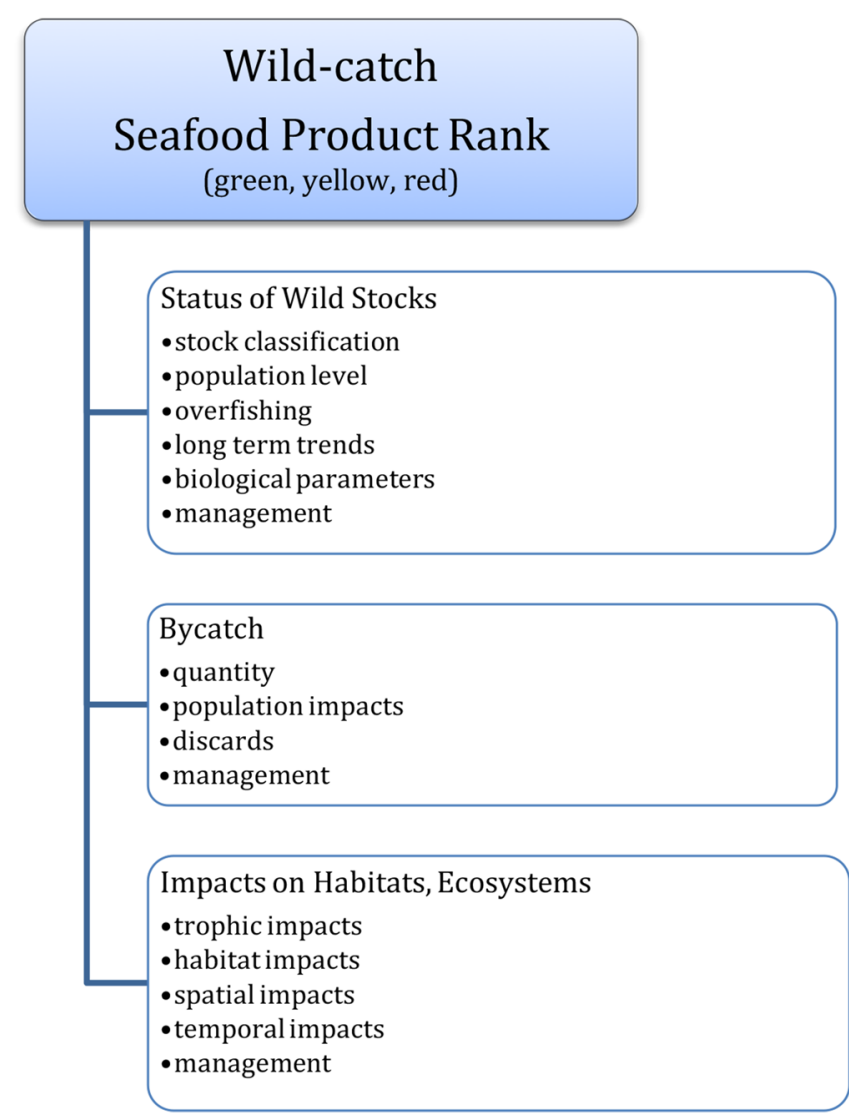

Figure 2. Overview of the SASAP Criteria and Sub-criteria assessment hierarchy for wild-caught seafood products

criteria cover the four equivalent central elements (Figure 3): disease and parasite risk; siting and cumulative impacts; wildlife interactions; and sustainability of wild-sourced stock and food sources.

\section{Decision Procedures}

In any assessment system that evaluates performance, the criteria need to be set in a performance grade using performance indicators relative to benchmarks with specified thresholds between classes (grades) of performance. Where possible, such systems should also provide specific guidance about both interpretation of the thresholds and an example set of interpretations and decisions that have been reached in a prior cycle of the decision process to demonstrate how the criteria have been applied in a specific situation that may have some form of general applicability (Ward 2008a). The thresholds may be set as pass/fail, or may be a graded set of thresholds of performance set in discrete categories (such as percentage bands). The greater the number of thresholds established, the greater the resolution achieved

taken by fishing gear, potentially disrupting local trophic relationships, energy flows, social behavior in protandrous or protogynous species, or other behavioural aspects of reproduction, such as aggregation for spawning, that may have much broader consequences for a population or ecosystem. Some forms of sedentary fauna are slow-growing and longlived, and even low intensity impact of fishing gear on these assemblages may have persistent and ecologically important consequences.

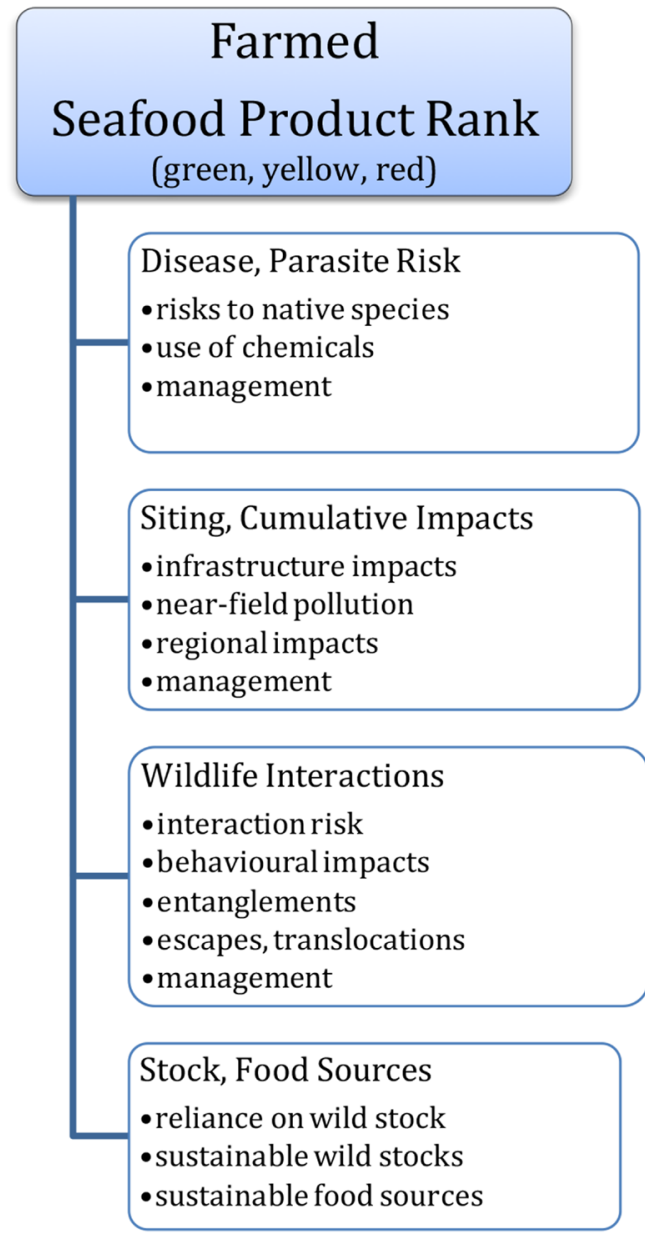

Figure 3. Overview of the SASAP Criteria and Subcriteria assessment hierarchy for farmed seafood products

in the assessment and its outcomes. However, at each increase in number of categories there is the parallel responsibility to ensure that the performance being assessed in each category is capable of being discretely resolved from the adjacent categories using the type of evidence likely to be available. In data-poor situations, the lack of information and data will preclude the use of fine scales of resolution. Performance bands must therefore be set that maximise the accuracy in decision criterion and decision outcome even if precision is reduced. And finally, where there turns out to be no useful data/knowledge that enables an informed and evidence-based decision to be made in relation to an indicator, the decision process must also specify how to treat that situation, such as assigning a default grade that is appropriately precautionary in the context of the specific decision problem being considered.

Given the limited data and knowledge base for many of the products being assessed, the SASAP criteria were established to match the three SW thresholds (red, yellow, green, and their associated language statements). Within each criterion in the SASAP, there is a set of sub-criteria (Figures 2 and 3), for each of which there is a performance indicator set with appropriate language-based grading guidance relative to an expected level of performance at the threshold. The number of sub-criteria that can be assigned as 'Unknown' is capped, above which a product is assigned with a Critical Concern (eliminating the product 
from the assessment), applying a precautionary base to the assessment process. The proportion of red, green, yellow and unknown indicator grades assigned to a product in the sub-criteria is proportionally balanced between farmed and wild-caught products. This is to ensure an equitable assessment structure that will minimise the risk of different performance standards between farmed and wild-caught products, and the consequent risk that environmental impacts may become exported from one sector to the other by consumer choice. Together with a defined structure for aggregating the performance grade from each indicator into a final decision for the product, this constitutes the decision structure adopted by the SASAP in order to provide an explicit, equitable, precautionary and transparent basis for any final product-level grade. Table 3 provides an example of the decision hierarchy for farmed products; an equivalent hierarchy was constructed and applied for assessment of wild-caught products.

Table 3. Example of the decision hierarchy established within the SASAP to assess farmed seafood products, including the decision rules for aggregation of performance from the level of indicator to product grade.

\section{Sub-Criterion Grading}

\begin{tabular}{|c|c|c|c|}
\hline Criterion & Sub-criterion & Indicator & Grade assigned \\
\hline \multirow[t]{3}{*}{$\begin{array}{l}\text { I. Disease and } \\
\text { Parasite Risk }\end{array}$} & $\begin{array}{l}\text { I.I Risk of } \\
\text { spreading disease } \\
\text { and parasites to } \\
\text { native species }\end{array}$ & $\begin{array}{l}\text { There is a low risk of introduction, amplification or transmission; effective } \\
\text { controls are in place; independent research/monitoring shows no evidence } \\
\text { of introductions, amplification or retransmission from the facility; and, there is } \\
\text { substantive physical separation from likely receptor species (all these must be } \\
\text { satisfied) OR there are intensive recirculating systems with effective controls } \\
\text { on effluent release and there is substantive physical separation from likely } \\
\text { receptor species (all these must be satisfied) }\end{array}$ & Green \\
\hline & & $\begin{array}{l}\text { There is a low risk of introduction, amplification or transmission; limited } \\
\text { controls are in place; and, there is substantive physical separation from } \\
\text { likely receptor species (all these must be satisfied) OR Unknown (there is } \\
\text { inadequate evidence available to inform a judgement) }\end{array}$ & Yellow \\
\hline & & $\begin{array}{l}\text { There is a moderate or high risk of introduction, amplification or } \\
\text { transmission; OR systems with untreated or ineffectively treated water } \\
\text { exchange to outside environment near likely receptor species; OR likely } \\
\text { receptor species are heavily depleted (below } 20 \% \text { of unfished level), or } \\
\text { "endangered", "threatened" or "protected" under any state, federal or } \\
\text { international law (if any of these are satisfied the grade is assigned) }\end{array}$ & Red \\
\hline
\end{tabular}

\section{Criterion-level Grading}

\begin{tabular}{llll}
\hline $\begin{array}{l}\text { Criterion I } \\
\text { Disease and Parasite Risk }\end{array}$ & $\begin{array}{l}\text { Sub-criterion I.I Risk of disease } \\
\text { and parasites to native species }\end{array}$ & $\begin{array}{l}\text { Sub-criterion I.2 Input and } \\
\text { use of chemicals }\end{array}$ & $\begin{array}{l}\text { Sub-criterion I.3 } \\
\text { Management effectiveness }\end{array}$ \\
\hline \multirow{2}{*}{ Green } & Green & Green & Green \\
\cline { 2 - 4 } & Green & Yellow & Green \\
\cline { 2 - 4 } & Yellow & Green & Green \\
\hline Yellow & Yellow & Yellow & Green \\
\cline { 2 - 4 } & Green & Yellow & Yellow \\
\cline { 2 - 4 } & Yellow & Green & Yellow \\
\cline { 2 - 4 } & Green & Green & any* \\
\hline Red & Yellow & Green & Red \\
& Yellow & Yellow & Red \\
\hline Green & Yellow & Red \\
\hline
\end{tabular}

* = may be either $\mathrm{G}, \mathrm{Y}$ or $\mathrm{R}$, subject to other rules taking precedence.

\section{Product-level Grading}

\begin{tabular}{ll}
\hline Product Classification & Criterion Level Achievement \\
\hline Green & Any two or more Green and no Red grades \\
\hline Yellow & Four Yellow; OR any one Green and no Red grades \\
\hline Red & One or more Red grades \\
Critical Concern & Any Critical Concern** \\
\hline
\end{tabular}

** Under Criterion I Disease and Parasite Risk, a farmed product is classified as having a Critical Concern if there is evidence of the product associated with an ecologically significant disease or parasite introduction within the past 5 years. A product is also considered to have a Critical Concern if more than two of the sub-criteria are determined by the SRP to be 'Unknown'. 
In the SASAP, the process of assessing and grading products is conducted by the Science Reference Panel (SRP) in an iterative process with several checks and balances, including error-checking and a procedural fairness loop. The key elements of this decision process are the consensus decision-making process using a set of performance indicators with clear grading thresholds and specific precautionary default decisions to be assigned in the event that relevant and assessable data/information is not available to the SRP to inform an evidence-based decision about the performance level of an indicator.

The Science Reference Panel (SRP), the primary decisionmaking body for gradings in the SASAP, consists of seven technical experts drawn from the Australian science and fisheries academic and applied research community who can demonstrate an independence from the fishing or farming sector. Conflicts of interest within the SRP, when they arise, are documented and SASAP decisions do not involve any member of the SRP who declares such a potential conflict of interest. The SRP members are identified in the public domain, and are collectively responsible for ensuring the fidelity of the gradings and the final SASAP decisions. Only products meeting the SASAP Green or Yellow grades are posted into the public domain, to avoid the concept of a

Table 4. The SASAP decision procedure workflow. 'black-list', and to enable producers who wish to upgrade their performance to engage privately with the SRP to demonstrate improvement without the complications of a public performance profile.

Products to be assessed are chosen on a non-voluntary basis - the SRP determines which products will be assessed for the SASAP without consultation with the relevant producer. Products for assessment are chosen because they represent important components of local ecosystems and habitats, and make at least a modest contribution to the local seafood economy. The procedures for product assessment follow a specified pathway to ensure the assessment for all products is systematic (Table 4). All draft product grades and the associated decision-basis are reviewed by at least one technical peer-reviewer, and by the producer prior to public release of a product grading. The SRP reviews all comments and responses to amend and confirm as necessary the details of the product decisions prior to public release.

Typical seafood products that have been assessed as meeting the ecological integrity criteria of the SASAP at the Green or Yellow level in the past include:

- Red Emperor from the Pilbara trap fishery-this is a highly-targeted low-impact fishery operating on the

\begin{tabular}{|c|c|c|c|}
\hline Stage & Action & Outcome & Documents \\
\hline I. Initial Listing & $\begin{array}{l}\text { SASAP researcher develops initial } \\
\text { list of products for preliminary } \\
\text { screening }\end{array}$ & $\begin{array}{l}\text { Initial List: product name, } \\
\text { type, producer, location }\end{array}$ & $\begin{array}{l}\text { Major research documents \& data } \\
\text { availability; major issues - stock, } \\
\text { bycatch etc; Critical Concerns } \\
\text { (CC) identified }\end{array}$ \\
\hline 2. First Screen & $\begin{array}{l}\text { Science Reference Panel (SRP) } \\
\text { chooses products for initial } \\
\text { evaluation }\end{array}$ & $\begin{array}{l}\text { Products Under Assessment } \\
\text { list }\end{array}$ & $\begin{array}{l}\text { Document and information base } \\
\text { by product; potential CC identified }\end{array}$ \\
\hline 3. Assessment Products & $\begin{array}{l}\text { Assessments List is reviewed by } \\
\text { SRP (remotely) }\end{array}$ & Final Assessments List & $\begin{array}{l}\text { Additional product information; } \\
\text { sensitive issues; CC detail }\end{array}$ \\
\hline 4. Assessments conducted & $\begin{array}{l}\text { SASAP researcher conducts } \\
\text { product assessments and compiles } \\
\text { draft assessment reports }\end{array}$ & $\begin{array}{l}\text { Initial Draft Assessment } \\
\text { reports for each product }\end{array}$ & $\begin{array}{l}\text { Initial Draft Assessment Report } \\
\text { for each product (confidential) }\end{array}$ \\
\hline $\begin{array}{l}\text { 5. SRP assessments } \\
\text { workshop }\end{array}$ & $\begin{array}{l}\text { SRP convenes in workshop } \\
\text { to consider, revise, approve } \\
\text { assessments }\end{array}$ & $\begin{array}{l}\text { SRP approved draft } \\
\text { assessment report for each } \\
\text { product, identifying any } \\
\text { further issues, uncertainties } \\
\text { to be reviewed, revised }\end{array}$ & $\begin{array}{l}\text { SRP Initial Draft Assessment } \\
\text { Report for each product } \\
\text { (confidential) }\end{array}$ \\
\hline 6. SRP final draft reports & $\begin{array}{l}\text { SRP considers revised Assessment } \\
\text { Reports, approves release to } \\
\text { reviewers }\end{array}$ & $\begin{array}{l}\text { SRP Draft Assessment } \\
\text { Report approved for release } \\
\text { to Peer Review }\end{array}$ & $\begin{array}{l}\text { SRP Review Draft Assessment } \\
\text { Report } \\
\text { (confidential) }\end{array}$ \\
\hline 7. Peer Review & $\begin{array}{l}\text { SASAP distributes draft } \\
\text { assessment reports to at least } \\
\text { one independent expert reviewer }\end{array}$ & $\begin{array}{l}\text { Peer review report for each } \\
\text { product, revised as necessary }\end{array}$ & $\begin{array}{l}\text { SRP Peer Reviewed Draft } \\
\text { Assessment Report for each } \\
\text { product (confidential) }\end{array}$ \\
\hline 8. Producer Review & $\begin{array}{l}\text { SASAP distributes peer-reviewed } \\
\text { draft assessment reports to the } \\
\text { producer for comment }\end{array}$ & $\begin{array}{l}\text { Producer comments on } \\
\text { draft assessment report } \\
\text { (procedural fairness loop) }\end{array}$ & $\begin{array}{l}\text { SRP Draft Assessment Report for } \\
\text { each product (confidential) }\end{array}$ \\
\hline $\begin{array}{l}\text { 9. SRP final assessment } \\
\text { reports }\end{array}$ & $\begin{array}{l}\text { SRP reviews, amends, finalises full } \\
\text { assessment report (remotely) }\end{array}$ & $\begin{array}{l}\text { Final Assessment Report } \\
\text { issued to producer, including } \\
\text { clarifications of any specific } \\
\text { weaknesses, options for } \\
\text { improvement }\end{array}$ & $\begin{array}{l}\text { Final Assessment } \\
\text { (confidential) }\end{array}$ \\
\hline 10. Public Distribution & $\begin{array}{l}\text { Summary of the product findings, } \\
\text { with grading, placed on the } \\
\text { SASAP website. }\end{array}$ & $\begin{array}{l}\text { Final decision of SASAP, } \\
\text { summary of features, } \\
\text { including duration timeframe }\end{array}$ & $\begin{array}{l}\text { Final Decision issued to website } \\
\text { (public domain) }\end{array}$ \\
\hline
\end{tabular}


North-west Shelf of Western Australia, with very limited bycatch; compared to adjacent trawl fisheries for the same species, the trap fishery is benign;

- farmed Mussels from Port Phillip Bay, Victoria-this farming system requires no feed inputs (the mussels feed on the local wild plankton), has minimal bottom contact or provisioning of surfaces as habitat to support invasive species, and has only minor site impacts;

- seacage Barramundi from Cone Bay, West Kimberleythese fish are farmed in an area remote from other activities, in a high-flow bay that provides a large assimilative and dispersive capacity for the fish wastes, with no nutrient sensitive habitats in close proximity.

The full list of products that have been assessed as Green or Yellow within the SASAP pilot project, together with details of the SRP and the SASAP Criteria are available at $<$ aussiegoodfish.weebly.com $>$. Note that the SASAP requires a full re-assessment each 3 to 5 years, depending on the specific circumstances of each product.
The product gradings of the SASAP pilot project have not been renewed and therefore have now all expired, pending renewal of SASAP funding.

\section{Market Testing}

To assess the practical value of the SASAP decision process, the relevance of the criteria, and the direct interest of consumers in the SASAP ratings system, a marketplace project was conducted at South Melbourne Markets in 2013-14 (Figure 4). Market research analysts were engaged by ACF to interview consumers and resellers, and to report on their perceptions of the SASAP and the extent of engagement and interest from various points in the local seafood supply chain. The findings indicated that the SASAP was well accepted, and all levels in the supply line responded favourably to both the technical ratings and their representation in the market (Frankel et al. 2013; Box 1). The local seafood industry had also responded positively, and, in 2011 the pilot

Box I. Market analysis of the SASAP in Victoria (from Frankel et al. 2013; extract reproduced with permission of the Australian Conservation Foundation)

\section{Program Overview}

The strength of the SASAP is that it assesses local species, caught by local small-scale fishers, thereby establishing a clear transparent link between the environment where the fish is caught, the supply chain through which it passes, and the end-consumer. In most cases the consumer can closely relate to the place where the fish is caught - e.g. a Melbourne consumer eating fish caught in the Port Philip Bay.

\section{Supply Chain Issues}

When working within the model of the local food economy it is relatively easy to manage the supply chain relationships, since these relationships are already in place and many of the people involved are known to each other and have a history of co-operation. The key is to keep the scale small and local. Through partnering with producers, wholesalers and suppliers in the supply chain it is possible for a program to source and market local, sustainable caught, fresh product.

\section{Consumers}

People we spoke with enjoy eating local fish and seafood. Seafood is viewed as a premium food product. They have varying views about what exactly is local and what exactly the definition of fresh is, but by and large their views fit with Victorian fish being local in Victoria, and 24 hours or thereabouts, being "fresh".

They want to support the local food economy. It is viewed by many as an intrinsically good thing. Others are not invested in this idea, but no one is opposed. They respond well to stories about the local food economy, the fishers, and the ecology.

Fishing sustainability is on the radar of ecologically concerned consumers - but it is more relevant for some than others. While local fishing sustainability is not on their radar, they easily understand the proposition and recognise it as adding value at the level of the local economy, ecology and as a premium product from a consumer perspective.

Ecologically concerned consumers of seafood tended to be regular shoppers at various local Melbourne markets Preston, Footscray, Prahran, South Melbourne, Dandenong.

\section{Summary Findings}

As we progressed with the research we realised that we were exploring a submerged story about the local seafood economy'. People experienced in developing and marketing land-based local food economies had useful insights to complement the knowledge of those working in the fishing and fish marketing industries. The public want to hear the story of the local seafood economy.

They want to eat the seafood. They want to support and maintain a healthy system of fishers and fish, and they will pay a premium for it.

\section{Sources}

The research, analysis and findings are based on desk studies, and 15 in-depth interviews and two focus groups with industry stakeholders and consumers: fishing industry bodies, fishers (Lakes Entrance, Port Phillip Bay, Corner Inlet), the state government fishery agency, local government (Melbourne, Port Phillip, Mornington), South Melbourne Markets, trend experts, social enterprise entrepreneurs, and corporate caterers. 


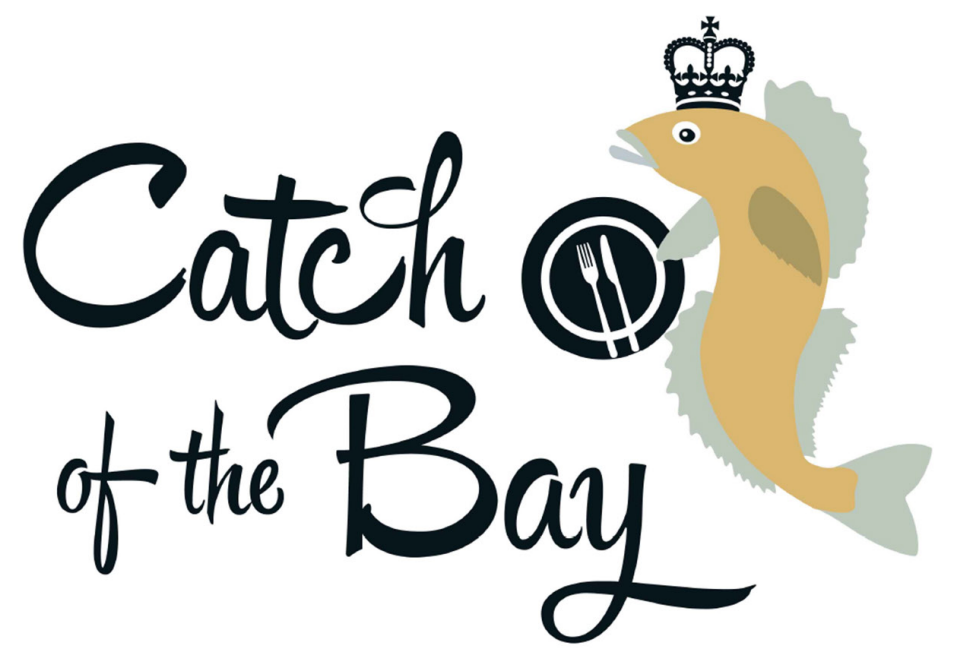

\section{Choose Local, Choose Sustainable -Protect our Oceans}

Seafood is a staple on the Australian table. But what looks great on your plate can be even fishier than it appears.

Australia imports roughly $72 \%$ of its seafood. We don't always know the source of the seafood we're eating or if it was harvested within the natural limits of our oceans.

Choosing fresh, local and sustainable is the best way to shop with confidence.
Leading marine scientists have sized up Victoria's fishers to make sure that their fishing practices have minimal impacts on the region's stocks, bycatch and habitat.

Scientists work closely with Port Phillip Bay and Corner Inlet fishers during the sustainability assessments to create a fish wish list that you can trust, hook, line and sinker.

Find the full list of sustainable seafood at: acfonline.org.au/seafood

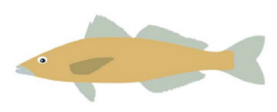

King George whiting
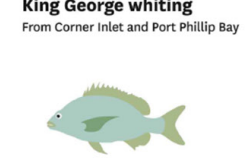

Black bream From Gippsland Lakes

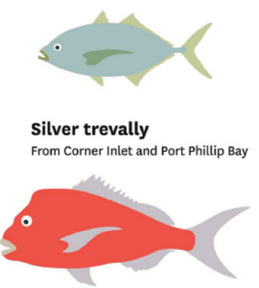

Snapper

From Port phillip Bay

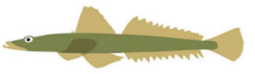

Rock flathead

From Corner Inlet

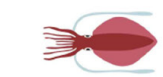

Southern calamari from Corner Inlet and Port phillip

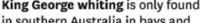
in southern Australia in bays and tshery uses erofully sip Bay seines and mesh nets to catch Whiting are caught in ti the corner
inlet fishery using small boats and specialised techniques that minimise impacts on
bycatch and habitat.

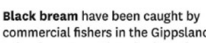
akes in eastern Victoria since the late 1800 s. It lives in estuaries can as long as as years, Fishers in
the Gippsland lakes use specialised gear, slow hauling and hand sorting

Silver trevally live in sandy areas near estuaries, beaches, bays and inshore coastline. In Port phillip Bay the fishers harvest from their fishery. In corner
Inlet the small number of fishers use Inlet the small number of fishers use
specialised fishing gear and hand sorting to min
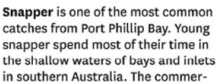
in southern Australia. The commer-
cial fishery in Port Phillip is relatively small and they use carefully selected
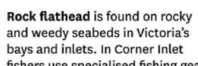
fishers use specialised fishing geet
and hand sorting to minimise habitat damage and the cat

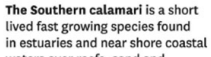
in estuaries and near shore coasta
waters over reefs, sand and seagrass areas. In Port Philip Bay the fishers use gear that have minimal impacts on stocks, bycatc and habitat. In Corner inlet the
small fishery havest calamari using
specially designed fishing gear to

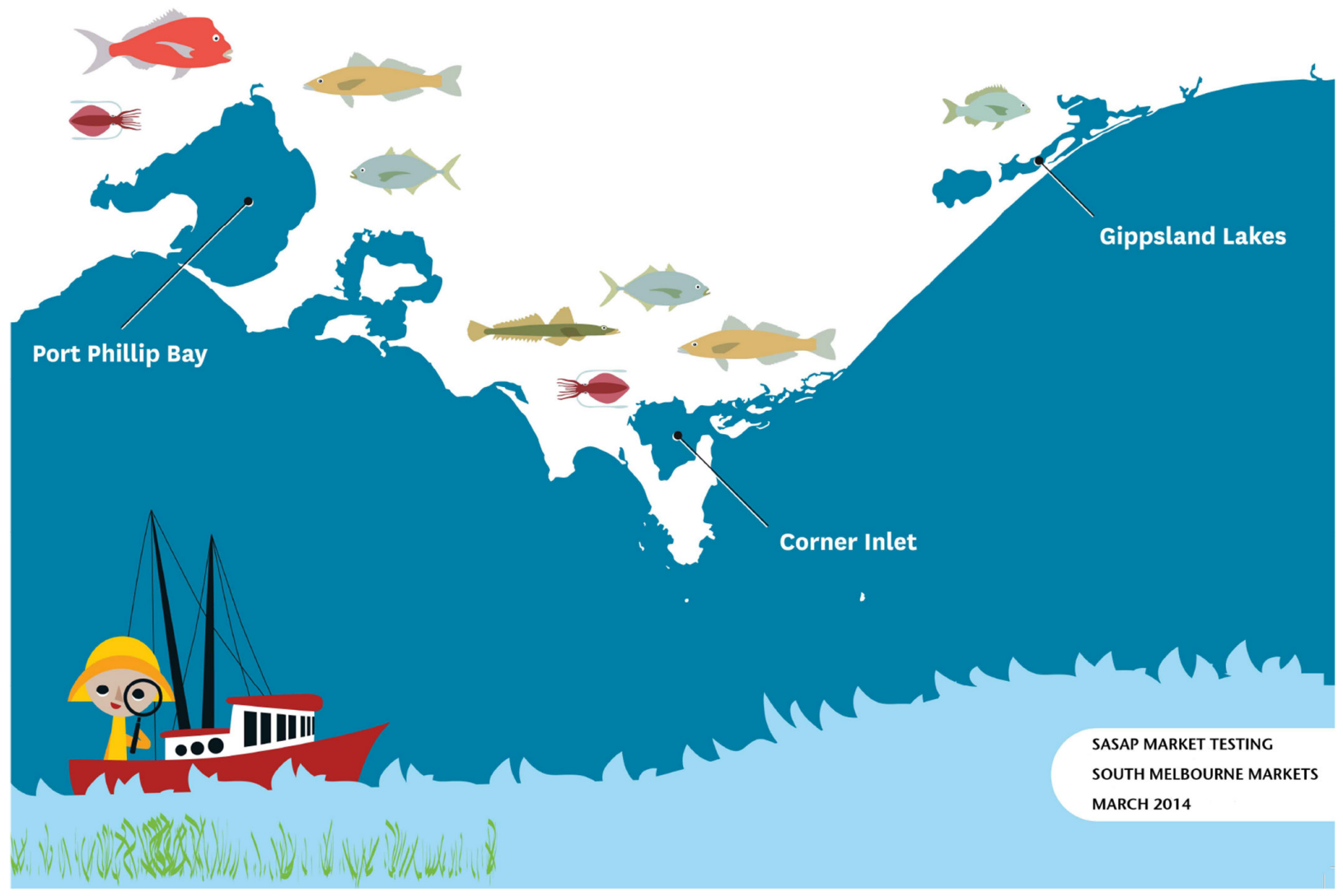

Figure 4. Poster used to engage wholesalers, retailers and consumers with the market testing program conducted at South Melbourne Markets.

(Reproduced with permission from the Australian Conservation Foundation and the University of Technology Sydney). 
SASAP project received the Seafood Industry Victoria 2011 Award for Seafood Industry Promotion.

\section{Key Differentiating Attributes}

The SASAP is different from the other programs we reviewed in five aspects that appear to be very important in the assessment and performance grading of locally produced seafood in Australia. These differences, apart from the higher level of accessibility and relevance to local producers, mainly distinguish the SASAP because of its higher effectiveness in grading products for their impacts on ecological integrity. This arises from our focus on ecological issues, making a contribution to ESD, all of which appears to be a close match to both the consumer perception and the definition of ecological sustainability and ESD.

First, the SASAP considers products rather than species or stocks as the unit of seafood that is assessed. This is more relevant for the 'local seafood economy' because some species are fished/farmed in different ways in different jurisdictions, and even at some locations, and this may confer different sustainability characteristics on a species. The SASAP therefore assesses wild-catch products defined by species, the form of fishing, and by location. In the case of farmed products, products are defined by species and by local producer or farm. So, for example, Red Emperor is caught by both a trap fishery and a trawl fishery on the North-west Shelf, but the SASAP assessment only endorsed Red Emperor from the trap fishery (the trawl fishery was not part of the pilot assessment). This focus on products enables the SASAP to be specific and directly relevant to key elements of the local seafood economy. Also, direct post-assessment engagement with producers is easier, and helps to develop a common language and understanding of the ecological issues, and connections to local consumer confidence, employment opportunities, and ongoing support for intergenerational family businesses and social structures.

Second, the SASAP criteria and indicators are uniquely focused on ecological issues and the impacts associated with local fishing activities. Empirical attributes of fished and farmed species populations are used in the SASAP to establish benchmarks and standards for seafood products that broadly represent consumer expectations about ecological sustainability, and can be used to report on the actual intent of ESD, reducing the scope for 'pseudosustainability' policies and programs in the seafood sector. The commonly available data, although sometimes highly limited, can be used in the SASAP as proxies to inform the empirical estimates of performance with an acceptable level of accuracy and precision within the grading system, and this is coupled with a representation of uncertainty that provides for precautionary decision outcomes. Lack of information and a high proportion of unknowns default to a precautionary grading outcome, rather than being mainly assessed through risk procedures or simply allowed to pass through the assessment system in a neutral manner.

Third, the use of a single public-domain expert-jury for all assessments, rather than various certification accreditation bodies that are contracted by producers, governments or NGOs for each assessment. Any significant form of financial control over certification processes enhances the risk of a controlling relationship and frame bias being developed in sustainability assessments. A typical result of this situation is the application of different assessment standards by accreditation bodies based on a different interpretation of the expected performance required by the standard, which may tend to systematically favour one specific form of interpretation over another (Ward 2008b). Producers and governments purchasing accreditation body services typically go 'certifier shopping', to seek the most favourable grading outcomes in exchange for an agreed financial return, or priority access to other related incentives such as bids for other activities within the industry sector. The SASAP assessments are not directly funded by producers, industry bodies or governments, limiting the opportunity for undue external influence on the findings. However, the corollary is that funding for the SASAP operations has to be sourced from independent 3rd party donors, and maintaining a consistent flow of funding support and related program of assessments can therefore be a significant problem.

Fourth, the SASAP conducts non-voluntary assessments. Products for assessments are chosen because they represent important components of local ecosystems and habitats, and make at least a modest contribution to the local seafood economy. This also, as above, avoids the requirement for a seafood producer or industry body to establish a structural (or financial) arrangement with an accreditation body to conduct contracted assessments. The SASAP nonvoluntary assessment model is typically based on use of public domain information, and largely avoids the need for access to privileged information (which may be available under a contracted arrangement but will not have been open to external scrutiny and verification), instead relying on public-domain and more openly contestable evidence as the basis for the SASAP grading outcomes. While there is occasionally a need for commercially sensitive knowledge (such as commercial earnings) to be held as confidential, the use of public domain knowledge in the SASAP assessments encourages producers to make all relevant data and information available in the public domain, increasing both the level of transparency in an assessment and consumer-confidence in the outcome.

Finally, the SASAP is a low-cost assessment system compared to almost all the other systems we reviewed and requires only minimal engagement (and hence cost) by a producer, unless they wish to present supporting data and information. This is principally because the assessments are conducted by the expert jury based on public domain data/information, with annual desk-review for a maximum of 4 years, and a minimal requirement for documentation of the findings beyond the reasoning behind the grade awarded to each individual criterion and the product. This makes the SASAP accessible and relevant to small-scale seafood producers marketing their products locally. This focus on local products also largely precludes the need for extensive chain of custody audits, as local marketplaces are usually well-informed about the exact source of fresh produce, and verification of specific practices is usually easy and robust given short supply lines and local knowledge amongst the fishing 
and farming industries. The local connections to seafood producers also enables small research studies to be easily established, focused specifically on matters important for the assessment and providing targeted assistance to the producers at low cost. Local products also minimise "carbon cost" of seafood sourcing, although this isnt directly part of our assessment process.

\section{Conclusions}

There is a currently unmet demand from consumers for an independent (from government and the industry) ratings system for Australia's locally produced seafood that is technically robust, transparent, non-voluntary and directly addresses ecosystem integrity. We base this conclusion on the high level of acceptance and endorsement by consumers expressed during the pilot marketing project for the SASAP in the South Melbourne Markets, and the endorsement and a marketing award for the SASAP from the local seafood industry.

The development and practical application of the SASAP demonstrates that a set of carefully chosen and robustly applied empirical proxies can be used to assess the ecological impacts of fishing and aquaculture operations. While the resolution of these proxies can be limited, their accuracy and precision is still adequate, given a set of wellconstructed decision criteria and precautionary default gradings, to enable a robust and defendable assessment of the ecological impacts of production of local seafood that matches consumer expectations.

The development and pilot implementation of the SASAP has confirmed that there are small-scale coastal fisheries that demonstrably conform to high standards of ecological sustainability, even though they are not certified by a major international 'sustainability' program. It is clear then, that the lack of a major ecolabel or accredited performance rating does not necessarily imply a lack of 'sustainability' of these small-scale fished and farmed products, rather it may imply a lack of access to an expensive certification program.

Overall, we observed significant frame-bias in respect of ecological issues in most of the assessment programs we reviewed here, including industry-leading programs. We consider that, as the human and climate change pressures increase on Australia's marine species and habitats, it will continue to be important to properly inform consumers about ecological impacts of their seafood choices. Government and industry 'sustainability' guarantees and compliance with the principles of ESD appear to have avoided the core ecological issues, and be more in keeping with the more general 'pseudo-sustainability' (sensu Burnett 2015) policies adopted to implement ESD. Balanced information about the ecological impacts associated with seafood production is also important as Australian consumers continue to contemplate their choices between imported seafood and locally sourced products, and particularly to avoid exporting any excessive impacts of seafood consumption to sources outside Australia. Despite this, an ecologically based affordable and independent assessment process for seafood, linked to consumer information systems, remains an elusive goal in the Australian seafood consumer marketplace.

In the short term, while we await better government, $\mathrm{NGO}$, and possibly industry leadership in these areas, we offer a few consumer tips to draw on when you next want to make a thoughtful choice of a seafood product (Box 2).

Box 2. Some leading questions that consumers can ask of their seafood reseller at a point of sale

- What species is this product (name standards are not mandatory)?

- Where does this product come from (country, region, state)?

- Which fishery or farm is the source (reliable suppliers will always know)?

- How is the product caught or farmed (what type of fishing gear; sea-cages; land-based ponds)?

- Is there a (current) sustainability assessment conducted by independent (of industry or government) and expert (with ecological expertise) authority, and what did they find (their ratings)?

- Who pays for these environmental assessments and reports if they are done (government, industry or $3^{\text {rd }}$ parties)?

- Is all the sustainability information easily available in the public domain (and if so where can I access it)?

\section{Acknowledgements}

We gratefully acknowledge the substantial financial and staff support of the Australian Conservation Foundation; several non-profit donors - principally the Lord Mayors Charitable Foundation Melbourne and the Ruffin-Falkiner Foundation; pro bono support from law firm Mallesons Stephen Jaques and catering company Delaware North; and University of Melbourne Department of Zoology (now School of BioSciences) for provision of meeting facilities. The ongoing program of activities is now based at University of Technology Sydney, operating in partnership with the authors. We are also grateful for the assistance of peer reviewers and independent researchers from the seafood research community in Australia who have provided reviews and detailed analysis of specific issues, and anonymous reviews of this manuscript. We also acknowledge the encouragement of Seafood Industry Victoria, and the members of the SASAP Advisory Panel, recognising the importance of this work for Victorian commercial fishers. Further information about the criteria and indicators, the SRP and SASAP decision framework is available at <aussiegoodfish.weebly.com>. SASAP activities are currently suspended pending further funding from independent sources. 


\section{References}

Atlas of Living Australia 2015. http://fish.ala.org.au. Accessed 19 November 2015.

Burnett, P. 2015. What Are We Really Trying to Achieve? Australian Environmental Meta-Policy Objectives Since 1970. Australian Government, Parliamentary Library, Summer Scholars Paper, May 2015. ISSN 2204-1982. Accessed 12 April 2016.

Caton, A. and McLoughlin, K. (eds.). 2000. Fishery Status Reports 1999, Bureau of Rural Sciences, Canberra, 2000. 250pp. <http://data.daff.gov.au/data/warehouse/fishrp9abc_011/ fishrp9abc_0110111a/FishStatusReport1999.pdf > Accessed 12 April $20 \overline{0} 16$.

Flood, M., Stobutzki, I., Andrews, J., Ashby, C., Begg, G., Fletcher, R., Gardner, C., Georgeson, L., Hansen, S., Hartmann, K., Hone, P., Horvat, P., Maloney, L., McDonald, B., Moore, A., Roelofs, A., Sainsbury, K., Saunders, T., Smith, T., Stewardson, C., Stewart, J. and Wise, B. (eds.). 2014. Status of key Australian fish stocks reports 2014. Fisheries Research and Development Corporation, Canberra. <http:// fish.gov.au/Pages/SAFS_Report.aspx > Accessed 12 April 2016.

Frankel, A., Major, D. and Bowden, R. 2013. ACF Research and Community Engagement Plan to Support Ongoing Work of the SASAP (Sustainable Australian Seafood Assessment Program). Alex Frankel and Associates, Research and Communications Strategy, Melbourne. Confidential commissioned research report for Australian Conservation Foundation, Melbourne, 17 Sep 2013.

Froese, R., Winker, H., Gascuel, D., Somalia, U. R. and Pauly, D. 2016. Minimizing the impact of fishing. Fish and Fisheries. Published online 6 Feb 2016. DOI: 10.1111/faf.12146

Gascuel, D., Coll, M., Fox, C., Guenette, S., Guitton, J., Kenny, A., Knittweis, L., Nielsen, J. R., Piet, G., Raid, T., Travers-Trolet M. and Shephard, S. 2016. Fishing impact and environmental status in European seas: a diagnosis from stock assessments and ecosystem indicators. Fish and Fisheries 17: 31-55. DOI: 10.1111/faf.12090

Industry and Investment NSW 2010. Status of Fisheries Resources in NSW, 2008/09, Mulloway. <http://www.dpi.nsw. gov.au/_data/assets/pdf_file/0007/375919/Mulloway.pdf> Accessed 12 April 2016.

Kemp, J., Brown, L., Bridge, N. and Conron, S. 2013. Gippsland Lakes Black Bream Stock Assessment 2012. Fisheries Victoria Assessment Report Series No. 42, March 2013. $<$ http://agriculture.vic.gov.au/fisheries/science-in-fisheries/ fisheries-research-findings/gippsland-lakes-black-bream-stockassessment-2012> Accessed 12 April 2016.

Leadbitter, D. and Ward, T.J. 2007. An evaluation of systems for the integrated assessment of capture fisheries. Marine Policy 31: 458-469. DOI 10.1016/j.marpol.2006.12.008

MEA 2005. Millennium Ecosystem Assessment, Ecosystems and Human Well-being: Synthesis. Island Press, Washington, DC. ISBN 1-59726-040-1. < http://www.millenniumassessment.org/ documents/document.356.aspx.pdf > Accessed 12 April 2016.

Melville-Smith, R. 2011. Factors Potentially Affecting the Resilience of Temperate Marine Populations. Report prepared for the Australian Government Department of Sustainability, Environment, Water, Population and Communities on behalf of the State of the Environment 2011 Committee. Canberra: DSEWPaC, 2011. < http://www.environment.gov.au/system/files/ pages/9bfalaca-538b-4594-bbb8-739923cd822a/files/soe2011supplementary-marine-factors-potentially-affecting-resiliencetemperate-marine-populations.pdf > Accessed 12 April 2016.

Palumbi, S., Sandifer, P., Allan, J., Beck, M., Fautin, D., Fogarty, M., Halpern, B., Incze, L., Leong, J-A., Norse, E., Stachowicz, J. and Wall, D. 2009. Managing for ocean biodiversity to sustain marine ecosystem services. Frontiers in Ecology and Environment 7: 204-211. DOI:10.1890/070135

Phillips, B.F. and Ward, T.J. 2009. Ecolabelling of sea food. Pesca y Conservación 1: 1-13. < http://espace.library.curtin. edu.au/R/?func $=$ dbin-jump-full\&object_id $=132610$ \&local_ base $=$ GEN01-ERA02 $>$ Accessed 12 April 2016.

Pitcher, T.J., Lam, M.E., Ainsworth, C., Martindale, A., Nakamura, K., Perry, R.I. and Ward, T.J. 2013. Improvements to Rapfish: a rapid evaluation technique for fisheries integrating ecological and human dimensions (Review Paper).Journal of Fish Biology 83: 865-889. DOI:10.1111/jfb.12122

SEC 2011. State of the Environment 2011 Committee. Australia State of the Environment 2011. Independent report to the Australian Government Minister for Sustainability, Environment, Water, Population and Communities, Canberra, DSEWPaC, 2011. www.environment.gov.au/topics/scienceand-research/state-environment-reporting/soe-2011/soe-2011report/6-marine. Accessed 11 April 2016.

Smith, A.D.M., Brown, C.J., Bulman, C.M., Fulton, E.A., Johnson, P., Kaplan, I.C., Lozano-Montes, H., Mackinson, S., Marzloff, M., Shannon, L.J., Shin, Y-J. and Tam, J. 2011. Impacts of fishing low-trophic level species on marine ecosystems. Science 333: 1147-1150. DOI: 10.1126/science.1209395

Stephan, M. and Hobsbawn, P. 2014. Australian fisheries and aquaculture statistics 2013, Australian Bureau of Agricultural and Resource Economics and Sciences, Canberra. November 2014, revn Dec 2014. http://data.daff.gov.au/data/warehouse/9aam/ afstad9aamd003/2013/AustFishAquacStats_2013_v1.2.0.pdf. Accessed 12 April 2016.

Ward, T.J. 2008a. Measuring the success of seafood ecolabelling. Pp. 207-246 in Seafood Ecolabelling Principles and Practice, edited by T.J. Ward and B.F. Phillips. WileyBlackwell, Oxford, UK.

Ward, T.J. 2008b. Barriers to biodiversity conservation in marine fishery certification. Fish and Fisheries 9: 169-177. DOI: 10.1111/j.1467-2979.2008.00277.x

Ward, T.J., Phillips, B.F. and Porter R. 2011. Lets get certified; Exploring the certification of farmed seafood. World Aquaculture. 42 no.3, September 2011: 31-36. < https://www.was.org/ Magazine/Contents.aspx?Id=39> Accessed 12 April 2016.

Ward, T.J. 2014. The condition of Australia's marine environment is good but in decline-An integrated evidence-based national assessment by expert elicitation. Ocean and Coastal Management 100: 86-100. DOI 10.1016/j.ocecoaman.2014.07.012 